\title{
Regime disciplinar diferenciado (RDD): um mal necessário?
}

\author{
Tatiana Moraes Cosate ${ }^{1}$
}

\begin{abstract}
"Cinco estudantes moram juntos. Em dado momento, um deles se arremessa contra a televisão e a quebra, quebrando, também, alguns pratos. Como irão reagir seus companheiros? Nenhum deles ficará contente, certamente. Mas, cada um, analisando o fato, serenamente, à luz da razão, poderá adotar uma atitude diferente. 0 estudante $n=2$, furioso, declara não poder mais conviver com o primeiro e fala em expulsá- lo de casa. $O$ estudante $n=3$ declara: Trata-se, sim, de comprar um novo aparelho de televisão e outros pratos, e que ele pague. O estudante $n$ ㅇ 4 , bastante traumatizado com o que acaba de acontecer, se exalta: Ele está seriamente doente; é preciso procurar um médico, fazer com que ele seja examinado por um psiquiatra etc. 0 último, enfim, murmura: Nós pensávamos que nos entendíamos bem, mas alguma coisa não funcionou em nossa comunidade, para que tal gesto tenha sido possível. Façamos todos juntos um exame de consciência." (grifo nosso).
\end{abstract}

Louk Hulsman

\section{Resumo}

O presente estudo tem como escopo analisar o regime disciplinar diferenciado. Inicialmente, apresenta o contexto histórico no qual surgiu esse tipo de sanção disciplinar, para, posteriormente, adentrar no seu conceito, onde se fez necessário a utilização da Lei de Execução Penal, especialmente no que diz respeito aos seus artigos 52 e 54 que tratam especificadamente do regime em comento. Na seqüência, enumeram-se as posições doutrinárias e decisões judiciais referentes à implementação do regime disciplinar diferenciado no sistema penitenciário brasileiro, destacando os argumentos utilizados pelos diferentes posicionamentos mencionados.

Palavras-Chave: Execução Penal; Regime Disciplinar Diferenciado; Direitos Humanos do Preso; Ressocialização da Pena; Direito Penal do Inimigo.

\section{Introdução}

Este artigo se propõe a analisar o regime disciplinar diferenciado (RDD), descrevendo o contexto histórico no qual surgiu, apresentando o seu conceito, bem como as posições doutrinárias a respeito da sua implementação nos presídios brasileiros.

1 Especialista em Direito Penal e Processual Penal pela Universidade Estadual de Londrina. 
Sabe-se que muitos autores já se debruçaram sobre esse tema. No entanto, o presente trabalho tem como finalidade e diferenciação a compilação das opiniões a respeito da utilização do regime disciplinar diferenciado como forma de sanção a ser imposta aos detentos, sejam eles provisórios ou definitivos. Para tanto, foi utilizada uma pesquisa bibliográfica diversificada, que inclui juristas, sociólogos e psicólogos. Observa-se que a maioria do material consultado consiste em artigos publicados em revistas especializadas no estudo da criminologia, pois poucos são os livros de execução penal que realizam uma análise crítica sobre o assunto, limitando-se a descrever os aspectos objetivos e subjetivos do objeto de estudo.

A importância dessa pesquisa reside na sua atualidade. No ano passado, o Estado de São Paulo foi vítima de inúmeros ataques realizados pelo Primeiro Comando da Capital (PCC), que tiveram como causa a imposição do RDD ao seu líder, Marcos Willians Herbas Camacho, mais conhecido como Marcola. Diante da notoriedade do caso, muitos doutrinadores voltaram a discutir sobre a constitucionalidade da imposição desse regime de execução mais severo. Dentre as várias opiniões adversas, destaca-se a que afirma que o RDD evidencia a adoção do Direito Penal do Inimigo, o que contraria todo o arcabouço jurídico do Estado Democrático do Direito, sobretudo no que se refere ao Princípio da Dignidade Humana.

Sem dúvida, a idéia primordial do legislador ao criar o regime disciplinar diferenciado foi separar e isolar os líderes de organizações criminosas dos demais presos, porque aqueles continuavam a comandar ações delituosas do lado interno e externo dos estabelecimentos prisionais. Talvez esse seja o caminho encontrado pelo poder constituinte derivado como forma de "salvar" o sistema penitenciário brasileiro do caos em que tem vivido nos últimos anos, principalmente a partir da década de 90, onde ocorreu um significativo aumento da população carcerária. Afinal, ninguém nega que a realidade nos presídios brasileiros não é "muito" boa. Faltam condições básicas de higiene, alimentação, saúde, sem contar a estrutura física deficitária, superlotação, agressões sexuais e inseguranças. Tudo isso faz com o que sistema atual seja considerado uma "faculdade do crime", totalmente arcaico, não cumprindo a sua principal função que é a ressocialização do preso. 
Assim, no afã de gerir a crise na segurança pública, a lei 10792/03 foi editada. Passemos, então, a analisar esse tema que é, ao mesmo tempo, apaixonante e conflitante.

\section{Desenvolvimento histórico do regime disciplinar diferenciado}

São Paulo, 18 de fevereiro de 2001: uma megarrebelião toma conta de 29 unidades prisionais da Capital, Região Metropolitana e Interior do Estado, atingindo cerca de 28 mil presos. Foi a maior rebelião até então registrada na história do Brasil. A ação foi coordenada pela facção criminosa Primeiro Comando da Capital (PCC) que protestava contra a transferência de alguns de seus líderes da Casa de Detenção do Carandiru para o Anexo da Casa de Custódia de Taubaté, considerada uma espécie de prisão de segurança máxima. Em decorrência dessa rebelião, a Secretaria de Administração Penitenciária de São Paulo edita, em 04 de maio de 2001, a resolução no. 26 que regulamenta a inclusão, permanência e exclusão de presos no Regime Disciplinar Diferenciado, destinado aos líderes e integrantes de facções criminosas ou àqueles cujo comportamento exigia tratamento específico. 0 objetivo era o recrudescimento do controle disciplinar no interior do cárcere que seria aplicado, inicialmente em cinco unidades prisionais: Casa de Custódia de Taubaté, Penitenciárias I e II de Presidente Vanceslau, Penitenciárias de laras e Penitenciária I de Avaré. O regime consistia no isolamento do detento por 180 dias, na primeira inclusão, e por 360 dias, nas demais, com direito "a banho de sol de, no mínimo, 1 hora por dia" e "duração de 2 horas semanais para visitas" (artigo 5o, incisos II e IV da Resolução 26/01).

Rio de Janeiro, ano de 2002: o presídio de segurança máxima Bangu 1 foi palco de uma briga entre as faç̧ões rivais (Amigo dos Amigos - ADA, Comando Vermelho e Terceiro Comando) que comandavam o tráfico de drogas na cidade, resultando na morte dos traficantes Ernaldo Pinto de Medeiros, o Uê, Wanderley Soares, o Orelha, e Carlos Roberto da Silva, o Robertinho do Adeus, todos líderes da ADA. Além dessas mortes, os líderes das mencionadas facções comandaram várias ações criminosas por toda a cidade. Nove bairros foram atingidos, 800 mil passageiros ficaram sem ônibus, parte do comércio fechou as portas. Indubitavelmente, esses fatos colocaram em debate o poder estatal de controlar ações criminosas comandadas de dentro do cárcere, pois, como observa Christiane Russomano Freire (2005, p. 150), o motim extrapolou "os muros das penitenciárias, externando seu controle e influência para o conjunto da sociedade". Em contrapartida, a 
Secretaria de Administração Penitenciária instituiu o Regime Disciplinar Especial. De acordo com Astério Pereira dos Santos ${ }^{2}$, secretário de Estado de Administração Penitenciária da época, o objetivo desse regime era:

\footnotetext{
Afastar líderes violentos e sanguinários, de exacerbada periculosidade, do convívio com os demais presos, que eles subjugam e usam como massa de manobra em suas rebeldias, obrigando-os a fazer rebeliões, motins e, até mesmo, greve de fome [...]. Afastar essa liderança de opressores dos demais presos, quase sempre criminosos ocasionais e eventuais, de escassa ou nenhuma periculosidade é, sobretudo, em ato de humanidade.
}

Vale dizer, isolar os presos que lideravam tais facções parecia a solução mais natural e plausível, de modo a interromper a cadeia de comando e desarticular o movimento, sintetiza o relatório elaborado pelo Conselho Nacional de Política Criminal e Penitenciária.

Diante desse contexto, o presidente Fernando Henrique Cardoso, como tentativa de universalizar o regime diferenciado via lei federal, envia ao Congresso Nacional o projeto de lei no 5.073 que alterava dispositivos da Lei de Execução Penal (LEP - no. 7.210/84) e do Código de Processo Penal (CPP) para, entre outras mudanças, permitir que presos de alta periculosidade que cometessem falta grave cumprissem pena no regime diferenciado a ser aplicado pelo conselho disciplinar. Cumpre observar que a implementação do RDD ganhou ênfase com os assassinatos de dois juízes corregedores da Vara de Execuções: Antônio José Machado Dias, de Presidente Prudente e Alexandre Martins de Castro Filho, do Espírito Santo. Ambos eram conhecidos nos seus Estados pelo tratamento severo dispensado aos presos no que se refere à concessão de benefícios. Assim sendo, no dia 10 de dezembro de 2003, a Câmara dos Deputados transforma o projeto 5.073/01 na Lei 10.792 , instituindo o Regime Disciplinar Diferenciado ${ }^{3}$.

2 Artigo retirado no site http://www.mj.gov.br/Depen/publicacoes/asterio santos.pdf. Acesso em 14 de janeiro de 2007.

3 Nesse intervalo temporal, o presidente Fernando Henrique Cardoso havia editado a Medida Provisória 28/02 que também pretendia inserir o regime disciplinar diferenciado na execução penal. Contudo, tal medida provisória, por violar o artigo $62, \S 1$ 으, I, "b" da Constituição Federal foi rejeitada pelo Congresso Nacional. 


\section{Conceito do regime disciplinar diferenciado}

O regime disciplinar diferenciado (RDD) é uma forma de sanção disciplinar que consiste no recolhimento do preso em cela individual, pelo prazo máximo de 360 dias $^{4}$. Nesse período, o detento tem direito a visitas semanais de duas pessoas, sem contar as crianças $^{5}$, com duração de duas horas e igual período diário de banho de sol. Diante dessas características, Mirabete (2004, p. 149) explica que:

o RDD não constitui um regime de cumprimento de pena em acréscimo aos regimes fechado, semi-aberto e aberto, nem uma nova modalidade de prisão provisória, mas sim um novo regime de disciplina carcerária especial, caracterizado por maior grau de isolamento do preso e de restrições ao contato com o mundo exterior. (grifo nosso).

Em Presidente Bernardes, por exemplo, os presos submetidos ao RDD utilizam algemas nas movimentações internas e a única ocupação oferecida são dois livros de leitura e um didático que podem ser requisitados semanalmente. Percebe-se, portanto, que as imposições decorrentes da submissão ao RDD configuram uma restrição provisória ao exercício dos direitos do preso elencados no artigo 41 da Lei de Execução Penal (LEP).

No que tange à aplicação do RDD, o artigo 52, alterado pela Lei 10.792/03, estabelece que todos os presos, maiores de dezoito anos, nacional ou estrangeiro, que estejam cumprindo pena em regime provisório ou definitivo, excetuando-se os que estejam recolhidos em razão de medida de segurança, estão sujeitos a esse regime. Continua a lei dizendo, no mesmo artigo, que o RDD somente pode ser aplicado em três hipóteses:

a) quando o preso comete falta grave equivalente à pratica de crime doloso que ocasiona subversão da ordem ou disciplina internas. É de notar que para a configuração dessa hipótese são imprescindíveis dois requisitos concomitantes: a prática de fato previsto como crime doloso e a conturbação da ordem ou disciplina interna do presídio. Dessa forma, esclarece Mirabete (2004, p. 150),

Esse prazo é de natureza penal, ou seja, segue a regra do artigo 10 do $\mathrm{CP}$, onde se inclui no cômputo do prazo o dia do começo, excluindo-se o dia final.

5 Ressalta-se que há duas opiniões doutrinárias a respeito da expressão "sem contar crianças" contida no inciso III do artigo 52. A primeira acredita que o legislador quis excluir esse tipo de visitas, pois o local e a forma dura do RDD poderiam lhe provocar um péssimo abalo psicológico, o que contraria o disposto no artigo 60 do Estatuto da Criança e do Adolescente (ECA). Já a outra posição acredita que a expressão "sem contar crianças" indica que elas não entram no rol de duas pessoas, podendo entrar quantas forem. 
para o fato que embora configure crime doloso não provoca a subversão da ordem e da disciplina, ou que é previsto como falta grave mas não como crime doloso, ainda que ocasione essa mesma subversão, são aplicáveis as sanções previstas nos incisos III e IV do art. 53.

b) quando o preso coloca em risco a ordem e a segurança do estabelecimento penal ou da sociedade. Segundo Luiz Flávio Gomes e outros ${ }^{6}$, essa segunda hipótese é o caso típico do preso que "dentro do presídio ou estabelecimento prisional" comanda "crimes do lado de fora do muro (extra muro), colocando em risco a sociedade e a própria milícia";

c) e no caso de recair, sobre o preso, fundadas suspeitas de envolvimento ou participação, a qualquer título, em organizações criminosas, quadrilha ou bando. Vale observar que a simples condenação pelo crime previsto no artigo 288 não autoriza, automaticamente, a inclusão no RDD. Ou seja, a lei não erige como pressuposto dessa hipótese a condenação anterior pelo crime de quadrilha ou bando, sendo que a retirada do preso do regime comum somente ocorre quando a sua associação criminosa coloca em risco a segurança da sociedade ou do estabelecimento penal.

Mirabete (2004, p. 151) esclarece que as hipóteses descritas nas alíneas "b" e "c" evidenciam uma inclusão cautelar do preso no RDD, vez que elas têm como finalidade

\footnotetext{
garantir as condições necessárias para que a pena privativa de liberdade ou a prisão provisória seja cumprida em condições que garantam a segurança do estabelecimento penal e a ordem pública, que continuaria ameaçada se, embora custodiado, permanecesse o preso em regime comum.
}

Por oportuno, saliente-se que o inciso I do artigo 52 da LEP prevê a renovação da sanção disciplinar, em caso de cometimento de nova falta grave de mesma espécie, até o limite de um sexto da pena aplicada. Assim, o RDD tem duração de um ano na primeira ocorrência. Já no caso de reincidência por falta grave, o limite temporal do RDD é de 1/6 da pena efetivamente aplicada, podendo ou não ser superior a 1 ano. Essa parte foi inserida em decorrência da orientação feita pelo secretário de Administração Penitenciária de São Paulo, Nagashi Furukawa ao Ministro da Justiça, Márcio Thomaz Bastos, já que a redação original do projeto de Lei 5073/2001 apenas previa a repetição da sanção pelo prazo máximo de 360 dias.

6 Artigo obtido no site http://www.bu.ufsc.br/ConstitRegimeDisciplinarDifer.pdf. 
Por fim, o artigo 54, $\S 1$ o, ressalta que a aplicação do RDD depende de requerimento circunstanciado elaborado pelo diretor do estabelecimento ou outra autoridade administrativa, respeitado o contraditório entre Ministério Público e defesa. Posteriormente, cabe à autoridade judicial prolatar sua decisão fundamentada, dentro do prazo máximo de 15 dias. Interessante observar que o artigo 60 da LEP permite a inclusão preventiva no RDD por dez dias que será, posteriormente, detraído do tempo a ser cumprido por decisão judicial. Essa inclusão preventiva, como ressalva a lei, somente é cabível quando o interesse da disciplina e da averiguação do fato assim a exigirem, podendo ser decretada pela própria autoridade administrativa, enquanto aguarda a decisão judicial. Todavia, opinião diversa é a do vice-presidente do Conselho Nacional de Política Criminal e Penitenciária e membro titular do Conselho Penitenciário do estado do Paraná, Mauricio Kuehne ${ }^{7}$, para quem o isolamento preventivo somente pode ser feito mediante autorização judicial.

\section{Posições doutrinárias sobre à implementação do regime disciplinar diferenciado no sistema penitenciário brasileiro}

Diante dos precedentes apontados, pode-se afirmar que o objetivo do legislador ao criar o regime disciplinar diferenciado era separar os líderes das facções criminosas do restante da população carcerária. Nesse sentido, oportunas são as palavras de Guilherme de Souza Nucci (2006, p. 961) para quem essa nova sanção disciplinar foi concebida

[...] para atender às necessidades prementes de combate ao crime organizado e aos líderes de facções que, dentro dos presídios brasileiros, continuam a atuar na condução dos negócios criminosos fora do cárcere, além de incitarem seus comparsas soltos à prática de atos delituosos graves de todos os tipos.

Dessa forma, criou-se a idéia de que a imposição do RDD aumentaria a segurança nos estabelecimentos penais, devolvendo ao Governo o controle interno dos presídios. Seguindo esse raciocínio, a intenção do legislador deveria receber apoio dos operadores de direito. Contudo, o cenário jurídico presenciou uma situação totalmente oposta. Vários questionamentos a respeito da constitucionalidade do regime disciplinar diferenciado foram externados. É que segundo entendem referida sanção disciplinar é uma determinação

7 Artigo obtido no site http://www.internext.com.br/valois/vec/art015.htm. 
"desumana de apartação da pessoa presa rotulada como ameaça à segurança nacional" (CARVALHO; WUNDERLICH, 2004, p. 6) ou um método de aniquilamento de personalidades, o que viola a dignidade humana e a integridade física do preso, conforme sintetiza Rômulo de Andrada Moreira (2006):

Cotejando-se, portanto, o texto legal e a Constituição Federal, concluímos com absoluta tranqüilidade ser tais dispositivos flagrantemente inconstitucionais, pois no Brasil não poderão ser instituídas penas cruéis (art. 5ํ, XLVII, "e", CF/88), assegurando-se aos presos (sem qualquer distinção, frise-se) o respeito à integridade física e moral (art. 5으, XLIX) e garantindo-se, ainda, que ninguém será submetido a tratamento desumano ou degradante (art. 5ㅇ, III).

De fato, os dispositivos constitucionais mencionados visam tutelar o indivíduo em face do arbítrio estatal punitivo, conferindo aos processados e condenados garantias processuais penais que assegurem a sua dignidade e inviolabilidade física, moral e psíquica. É o que o desembargador Marco Nahum da 1ạ Câmara Criminal do Tribunal de Justiça de São Paulo definiu como sendo "o equilíbrio entre a segurança e a liberdade individual, de maneira a privilegiar, neste balanceamento de interesses, os valores fundamentais de liberdade do homem" ${ }^{8}$, ao conceder o pedido de habeas corpus à detenta Priscila Rodrigues de Souza que se encontrava submetida ao RDD. Isso porque, deriva da concepção de Estado Democrático a obrigatoriedade de limitar o jus persequendi in judicio e o jus puniendi, tendo em vista que a intervenção penal é uma medida de extrema intimidação, com repercussão no status libertatis do preso, como esclarece Pedro Marcondes (2003, p. 251):

O respeito à dignidade da pessoa humana baliza toda política pública, concebendo o preso - antes da condição de criminoso - como pessoa humana, que como tal deve ser tratado. Esse enfoque exige que sejam humanizados os cárceres e dado um sentido positivo ao cumprimento da pena privativa de liberdade. O Estado tem o indeclinável dever de elaborar e executar políticas públicas que diminuam o sofrimento das pessoas condenadas, reduzindo os efeitos criminógenos das prisões e oportunizando os recursos necessários para que, ao obter a liberdade, estejam motivadas e em condições de viver como cidadãos.

8 Habeas Corpus n. 893.915-3/5-00. Voto no 9048. Obtido no site http://www.mailarchive.com/direitos humanos@yahoogrupos.com.br/msg01338.html. Nesse mesmo site, tem-se a íntegra do Hábeas Corpus concedido a Marcos Willians Herbas Camacho, o Marcola, pelo desembargador Borges Pereira, que determinou a sua remoção do regime disciplinar diferenciado, por entender que o mesmo viola os mais simples princípios constitucionais em vigor. 
E como forma de consolidar essa política criminal e penitenciária garantista, o Conselho Nacional de Política Criminal e Penitenciária (CNPCP) aprovou, em 11 de novembro de 1994, as Regras Mínimas para o Tratamento do Preso no Brasil que proíbem toda punição de natureza cruel, desumana ou degradante, como diz o "art. 24. São proibidos, como sanções disciplinares, os castigos corporais, clausura em cela escura, sanções coletivas, bem como toda punição cruel, desumana, degradante e qualquer forma de tortura."

Nesse mesmo contexto, têm-se as Regras Mínimas para o Tratamento de Prisioneiros da Organização das Nações Unidas, para as quais a detenção em cela escura, a redução de alimentação bem como as penas de isolamento configuram a aplicação de uma sanção desumana, cruel e degradante (artigo 31).

Assim, diante desse padrão mínimo que qualquer tipo de privação de liberdade deve obedecer, indaga-se se o RDD pode ser considerado uma pena desumana, cruel ou degradante. Será que manter um preso, em cela individual, durante 360 dias ou por até 1/6 da pena realmente ofende as garantias constitucionais referidas? Buscando uma definição do que seria uma pena cruel, Alexandre de Moraes (2005, p. 235) explica que:

[...] dentro da noção de penas cruéis deve estar compreendido o conceito de tortura ou de tratamento desumanos ou degradantes, que são, em seu significado jurídico, noções graduadas de uma mesma escala que, em todos os seus ramos, acarretam padecimentos físicos ou psíquicos ilícitos e infligidos de modo vexatório para quem os sofre.

De uma forma singela, portanto, pode-se afirmar que pena cruel é aquela que provoca sofrimento intenso e humilhação na pessoa, trazendo consigo uma acentuada ofensa à integridade humana. Cumpre observar que não existe legislação complementar que forneça o conceito preciso de tratamento desumano, cruel ou degradante. No entanto, como salientado pelo ex-Relator especial das Nações Unidas para a Tortura, Sir Nigel Rodley, o uso do conceito de tortura fornecido pela Convenção Interamericana para Prevenir e Punir Tortura pode ser pensada como abarcadora da maioria de atos que noutros lugares poderiam ser tratados como tratamentos cruéis proibidos ("prohibited ill-treatment") que não chegam a ser tortura. Assim, em face da ausência de uma definição precisa de tratamento desumano, cruel ou degradante, utiliza-se o conceito de tortura, uma vez que o mesmo permite afirmar "que, sendo esta um ato extremo, aqueles seriam uma versão 
mitigada daquela, dada a sua menor intensidade.E, de acordo com a mencionada Convenção ${ }^{9}$, tortura é:

Artigo 2․ [...] todo ato pelo qual são infligidos intencionalmente a uma pessoa penas ou sofrimentos físicos ou mentais, com fins de investigação criminal, como meio de intimidação, como castigo pessoal, como medida preventiva, como pena ou com qualquer outro fim. Entender-se-á também como tortura a aplicação, sobre uma pessoa, de métodos tendentes a anular a personalidade da vítima, ou a diminuir sua capacidade física ou mental, embora não causem dor física ou angústia psíquica.

Não estarão compreendidos no conceito de tortura as penas ou sofrimentos físicos ou mentais que sejam unicamente conseqüência de medidas legais ou inerentes a elas, contanto que não incluam a realização dos atos ou a aplicação dos métodos a que se refere este artigo.

Tendo em vista o conceito apresentado e a sistemática do RDD, o Conselho Nacional de Política Criminal e Penitenciária ${ }^{10}$ afirma que esse tipo de sanção disciplinar constitui uma pena cruel e desumana que ocasiona distúrbios psicológicos e psiquiátricos no detento:

\begin{abstract}
Este tipo de regime, conforme diversos estudos relatam, promove a destruição emocional, física e psicológica do preso que, submetido ao isolamento prolongado, pode apresentar depressão, desespero, ansiedade, raiva, alucinações, claustrofobia, e a médio prazo, psicoses e distúrbios afetivos graves. O projeto, ao prever isolamento de trezentos e sessenta dias, certamente causará nas pessoas a ele submetidas a deterioração de suas faculdades mentais, podendo-se dizer que $o$ RDD, não contribui para o objetivo da recuperação social do condenado e, na prática, importa a produção deliberada de alienados mentais.
\end{abstract}

Acompanhando esse posicionamento, Maria Adelaide Freitas Caíres (2006), psicóloga e membro do Conselho Penitenciário do Estado de São Paulo, reafirma que o confinamento isolado enfraquece a organização mental gradativamente do preso, até romper em um quadro psicótico. Ou seja, é uma garantia para se chegar à loucura absoluta. De acordo com a psicóloga, esse processo ocorre porque o "homem é um animal social, não adianta querer mudar isso. Sempre vivemos em companhia de alguém. É muito penosa a condição de não poder conversar com ninguém, de não poder expor e ouvir uma idéia, não

\footnotetext{
9 Dado obtido no site http://www.dhnet.org.br/direitos/sip/oea/oeatort.htm. Acesso em 10 de janeiro de 2007.

10 Relatório obtido no site http://www.mj.gov.br/cnpcp/. Acesso em 10 de janeiro de 2007.
} 
escutar nenhum barulho"11. Luiz Wolfmann, diretor de presídios paulistas, presenciou sintomas de insanidade dos presos que se encontram no RDD, como por exemplo, ouvir vozes vozes - quando não há ninguém conversando-, achar que todos estão falando mal dele e contra ele. Carmen Silvia de Moraes Barros (2006) também frisa que esse tipo de sanção disciplinar destrói a personalidade do preso, além de confirmar que:

\begin{abstract}
Ainda vigora o entendimento de que o preso está sujeito a uma relação especial de poder, muito embora da vigência da Constituição derive a obrigatoriedade da proteção dos direitos fundamentais do preso tanto pela autoridade judicial, quanto pela autoridade administrativa. É a confirmação de que ainda vige o entendimento de que há entre preso e administração penitenciária uma relação especial de sujeição e não uma relação que de direitos e deveres recíprocos, dos quais deriva para a administração, da qual depende o preso, o dever de proporcionar ou criar condições para o efetivo exercício de seus direitos.
\end{abstract}

Outro aspecto que revela a crueldade do RDD é o aniquilamento da integração social do condenado. É sabido que no Estado de Direito Democrático e Social, a pena cumpre dois papéis: retribuir o mal causado pela prática do crime e ressocializar o agente, readaptando-o à vida social, por meio de serviços e oportunidades colocados à sua disposição. Seguindo essa diretriz eclética, a LEP, no seu artigo $1 \stackrel{0}{\circ}$, estabeleceu como orientação primordial no cumprimento da pena o oferecimento de "condições para a harmônica integração social do condenado e do internado". Ademais, o artigo 5ㅇ, item 6, da Convenção Americana sobre Direitos Humanos ${ }^{12}$ dispõe que "as penas privativas da liberdade devem ter por finalidade essencial a reforma e a readaptação social dos condenados (grifo nosso). No entanto, adverte Carmen Silvia de Moraes Barros (2004, p. 185), a efetivação do RDD anula qualquer possibilidade de ressocialização do preso, além de potencializar o efeito da prisionalização, já que "quanto mais afastado se mantiver o condenado do convívio social, maior será seu envolvimento com a cultura do cárcere e sua dessocialização". Esse mesmo aspecto foi lembrado pelo Conselho Nacional de Política Criminal e Penitenciária, que classificou o RDD como sendo exemplo de vingança privada pelo ente público, no qual não há contribuição para que o "sentenciado retorne à sociedade

\footnotetext{
11 Entrevista dada à Revista Ciência Criminal. 0 Castigo que vai ao fundo da alma.. Site: http:cienciacriminal.uol.com.br/revista. Acesso em 15 de dezembro de 2006.

12 Dado obtido no site http://www.dhnet.org.br. Acesso em 14 de janeiro de 2007.
} 
de forma produtiva e harmônica"13. Aliás, como bem observou Elisangela Melo Reghelin (2006, p. 18), o RDD, com fins meramente retributivo e inocuizador, assemelha-se ao sistema primitivo de Filadélfia ou pensilvânico, no qual o preso era recolhido à sua cela, isolado dos demais em absoluto silêncio. Contudo, esse sistema foi duramente criticado porque impossibilitava a ressocialização do condenado, em virtude do seu completo isolamento, sendo substituído pelo sistema auburniano. Portanto, é "injustificável o retrocesso a um modelo fortemente assemelhado ao mais primitivo de todos, ou seja, o filadélfico, cujas conseqüências desastrosas a própria história conhece" (REGHELIN, 2006, p. 18).

Diante dessas considerações, firmou-se o entendimento de que o isolamento celular não é uma boa prática, recomendando a sua utilização em último caso, quando a administração carcerária não tenha outra escolha. Em estrita conexão com esse entendimento, o artigo 7 das Regras Mínimas para o Tratamento de Prisioneiros da Organização das Nações Unidas ${ }^{14}$ assentou o posicionamento de que o isolamento como forma de castigo é uma medida excepcional, aplicável mediante orientação médica que tenha examinado o preso e certificado por escrito que ele está apto a suportá-lo. É o que mutatis mutandi ficou estabelecido pela Resolução no. 10 do Conselho Nacional de Política Criminal e Penitenciária que certificou a desnecessidade do regime disciplinar de segurança máxima "para a garantia da segurança dos estabelecimentos penitenciários nacionais e dos que ali trabalham, circula e estão custodiados, a teor do que já prevê a Lei n. 7.210/84". Assim, conclui Carlos Weiss (2005, p.14), há patente descompasso entre as "previsões abertas e permissivas de inclusão do preso em RDD, contidas na Lei no. 10792/03, e o caráter extraordinário de tal punição, decorrente das exigências internacionais".

Ademais, há que se ressaltar o efeito inverso provocado pela imposição do RDD que consiste no aumento de rebeliões e revolta dos detentos, como a que ocorreu no dia 12 de maio de 2006 em São Paulo, onde policias e bandidos foram mortos em tiroteios, além de dezenas de ônibus assaltados e incendiados. Os ataques ocorreram depois que presos ligados ao PCC foram transferidos para a Penitenciária 2 de Presidente Venceslau, considerada prisão de segurança máxima na qual o RDD é imposto. O catedrático alemão,

13 Relatório obtido no site http://www.mj.gov.br/cnpcp/. Acesso em 10 de janeiro de 2007.
14 Dado obtido no site http://www.dhnet.org.br. Acesso em 14 de janeiro de 2007. 
Cornelius Prittwitz (2004, p. 33), durante sua palestra proferida no 9o Seminário Internacional do IBCCRIM, explicou que esse efeito inverso ocorre quando o direito penal é utilizado como forma de resolver todos os problemas. Assim, ao se aplicar esse pensamento, os problemas que se pretende resolver por meio do direito penal se intensificam, "devido à aplicação muito freqüente, muito rígida ou incorreta do direito penal". Acrescente-se a opinião do Conselho Nacional de Política Criminal e Penitenciária ${ }^{15}$, para o qual esse fomento à violência propiciado pelo RDD se deve ao exacerbamento dos:

aspectos psicológicos negativos do sentenciado e sua revolta contra os valores sociais. Assim, tão logo seja possível, tais presos passam a arquitetar meios de subverter a disciplina, organizando-se em estruturas hierarquizadas que acabam por envolver toda a população carcerária. Ao fim e ao cabo, todo o sistema penitenciário mostra-se mais e mais inseguro.

Da mesma forma, grande parte da doutrina entende que as hipóteses de aplicação do RDD violam o Princípio da Legalidade, especificadamente no que se refere à taxatividade das normas penais incriminadoras. De acordo com o mencionado Princípio, o tipo penal deve ser certo, claro, taxativo e prévio. Porém, nas hipóteses já analisadas no item 2, o legislador utilizou expressões vagas que dificultam precisar de forma inequívoca qual a conduta do preso que acarretaria a sua inclusão no RDD.

Por fim, outro argumento que corrobora a refutação à adoção do RDD é que ele pode ser considerado um reflexo do direito penal do inimigo ${ }^{16}$. Essa teoria foi desenvolvida pelo penalista germânico Günter Jakobs que, sustentando o contratualismo hobbesiano, defende a divisão da sociedade em dois grupos visivelmente separados: cidadãos e inimigos.

É inimigo a pessoa que mediante seu comportamento, profissão ou afiliação a determinada organização se afastou de modo permanente do Direito, vivendo em constante guerra contra o Estado, a exemplo dos criminosos econômicos, terroristas, autores de delitos sexuais e delinqüentes organizados. Zilan Costa e Silva (2006) ${ }^{17}$ explica que:

15 Relatório obtido no site http://www.mi.gov.br/cnpcp/. Acesso em 10 de janeiro de 2007.

${ }^{16}$ O penalista espanhol, Jesús Maria Silva Sánchez, substitui a nomenclatura "direito penal do inimigo" por direito penal de terceira velocidade. Para o mencionado autor, há três níveis (velocidades) diferentes de direito penal. O primeiro se caracteriza pela utilização da pena privativa de liberdade e a manutenção de forma estrita dos princípios políticos-criminais e processuais. A segunda velocidade já é mais flexível porque se compõe de infrações cuja pena é pecuniária ou restritiva de direito.

17 Artigo retirado no site www.ibccrim.org.br. Acesso em 14 de janeiro de 2007. 
O fundamento dessa construção está na idéia de que o Direito é uma relação entre pessoas que contêm direitos e deveres. Esta relação surge quando os indivíduos abrem mão de parcela de sua liberdade ao sair do estado de natureza e se submetem, adotando uma posição hobbesiana, à proteção do Estado.

Porém, o "inimigo" violou as normas desse contrato social o que ocasiona o seu retorno ao "estado de natureza", uma vez que se afastou de forma propositada e constante do Direito. Vale dizer, o "inimigo" tem "por princípio ideológico o repúdio ao ordenamento jurídico e almeja a destruição deste último, não fornecendo, portanto, a garantia cognitiva mínima necessária para o seu tratamento enquanto pessoa" (MALAN, 2006, p. 227). Ao agir dessa forma, o Estado passa a adotar um tratamento diferenciado em relação ao "inimigo", considerando-o uma séria ameaça à vida em sociedade, conforme afirma Jakobs (2005, p. 36):

\footnotetext{
Um indivíduo que não admite ser obrigado a entrar em um estado de cidadania não pode participar dos benefícios do conceito de pessoa. E o que estado de natureza é um estado de ausência de normas, isto é, de liberdade excessiva, tanto como de luta excessiva. Quem ganha a guerra determina o que é norma, e quem perde há de submeter-se a esta determinação.
}

Dessa forma, o Estado deixa de ter obrigações como, por exemplo, assegurar-lhe garantias constitucionais. Isso ocorre porque o "inimigo" não é um sujeito de direito e sim um objeto de coação, um foco de perigo a ser neutralizado. Assim, o Estado não apenas tem o direito de tratar indivíduos perigosos como não pessoas, mas sim o dever de fazê-lo.

Por outro lado, é cidadão todo aquele indivíduo que, embora tenha cometido um crime, almeja retornar ao seio social depois do cumprimento da pena. Para ele, o Estado deve ofertar e respeitar todas as garantias penais e processuais, já que o cidadão não se desviou das regras básicas de condutas sociais.

Diante desse conceito geral do que vem a ser uma parte da tese defendida por Günter Jakobs, muitas objeções doutrinárias foram levantadas, mas a principal, como ressalta Luís Greco (2005, p. 91), "foi o suposto direito do estado de recusar a seres humanos o status de pessoa: o conceito do direito penal do inimigo significaria uma volta a idéias nacional-socialistas a respeito da exclusão de determinados grupos". É exatamente por isso que a Lei 10792/03, que institui o regime disciplinar diferenciado, é considerada como percussora do direito penal do inimigo. Assim, seriam inimigos todos aqueles detentos 
que venham praticar crime doloso durante o período de segregação ou as demais hipóteses já analisadas e expostas no artigo 52 da LEP. Ao analisar esse tema, Bruno Seligman Menezes (2006, p. 19) comenta que ao erigir o apenado como inimigo:

\begin{abstract}
- Estado 'vinga' a sociedade de todos os problemas relacionados à criminalidade, segurança pública, incutindo nela - sociedade - um falso sentimento de segurança. [...] O que se está pretendendo fazer, desde a instituição do Regime Disciplinar Diferenciado é colocar o preso como inimigo da sociedade. Assim, um Estado ausente na sua função de Estado-provedor se faz presente na função de Estado-ditador, Estado-tirano, Estado-autoritário, e restringe direitos e garantias constitucionais, porque não tem competência, ou vontade política, de desenvolver uma política de inclusão social, que busque assegurar ao preso a ressocialização, não dentro das masmorras, mas fora delas, assegurando-lhe um emprego, uma remuneração digna, assistência social, psicológica. Entretanto, política desta natureza não é de fácil implementação, não traz retorno eleitoral imediato. É necessário semear hoje para colher em dez, quinze anos.
\end{abstract}

Realmente, ao se adotar esse paradigma defendido por Jakobs a sociedade tem a falsa ilusão de que a criminalidade organizada diminuirá e de que o Estado recuperará o controle dos estabelecimentos carcerários. No entanto, essa alternativa encontrada pelo Estado apenas reforça o caráter simbólico do direito penal como explica Elisangela Melo Reghelin (2006, p. 18):

O mero efeito simbólico serve, aqui, para aliviar o sentimento de insegurança pública, através do efeito ilusório gerado, bem como para aliviar necessidades psicossociais, já que é da natureza humana desejar ver no castigo alheio um bálsamo para seus próprios sentimentos de culpa, e também como um freio a certos impulsos delitivos.

Diante do exposto, a única certeza é de que o direito penal não pode ser encarado como instrumento de segurança da sociedade, porque essa visão ocasiona a sua intensa aplicação, bem como o endurecimento desnecessário das normas incriminadoras, das penas e do regime de sua execução, a exemplo do RDD. Portanto, é ilusório imaginar que o problema da violência criminal seja ela difusa ou organizada, será resolvido por meio da promulgação de leis penais severas e autoritárias que desrespeitam os direitos e garantias constitucionais. Outrossim, resume Roberto Delmanto (2006, p. 5), só “a diminuição do nosso enorme desnível social, a contínua luta pela erradicação dos bolsões de miséria, e o investimento na infância e na juventude nos darão um futuro melhor". Enfim, o "combate ao 
crime organizado só será eficaz com maciços investimentos sociais e em infra-estrutura" (grifo nosso).

Mas também existem os defensores da manutenção do RDD. Sustentam que a finalidade dessa sanção é legítima, já que busca um absoluto isolamento dos presos provisórios ou condenados que apresentam alto risco para a ordem e a segurança do estabelecimento penal ou sobre o qual recaiam fundadas suspeitas de envolvimento ou participação em organizações criminosas, quadrilha ou bando.

Acrescentam que a permanência de certos presos junto com os demais é extremamente prejudicial ao sistema carcerário, já que alguns detentos são líderes violentos e sanguinários, de exarcebada periculosidade. Assim, o isolamento celular e o afastamento dessa categoria de presos são necessários, como ressaltou Astério Pereira dos Santos $(2007)^{18}$ :

\begin{abstract}
Não se pode combater a escalada da criminalidade sem dar a essa maioria manipulada e oprimida a oportunidade de, ao menos durante o período de encarceramento, deixar de cumprir ordens do crime organizado. [...] Desse modo, aos criminosos que, mesmo aprisionados, pretendem continuar a exercer sua malévola liderança é imperioso que o Estado Ihes imponham um regime de disciplina diferenciado que, sem ser desumano ou contrário à Constituição, possa limitar os direitos desses presos evitando que eles, ao arrepio da Lei e do Poder Constituído, acabem por restringir os direitos da grande massa carcerária [...]. Não se ignora que o Estado tem na dignidade da pessoa humana o centro de sua atuação e sua própria razão de ser. Nem se pretende com o RDD suprimir a dignidade da pessoa do apenado, ao contrário se quer garantir que aqueles presos que compõem a grande massa carcerária possam dignamente cumprir sua pena e buscar rumos que os afastem da criminalidade.
\end{abstract}

Afirmam, ainda, que, em alguns casos, a função preventiva especial positiva da pena é inócua, tendo em vista a não disposição do autor do fato criminoso em se ressocializar.

Por fim, argumentam a proporcionalidade da medida, pois nenhum direito fundamental é absoluto. Ou seja, levando em consideração que os direitos fundamentais são sempre direitos prima facie e não definitivos, a imposição ou não de restrições dependerá da ponderação e valoração de cada caso concreto. Somente assim, é que se pode obter uma certa harmonização e determinação da prevalência de um direito sobre o outro. Em outras palavras, esse argumento confronta dois direitos fundamentais: a dignidade do preso em

18 Artigo retirado no site http://www.mi.gov.br/Depen/publicacoes/asterio santos.pdf. Acesso em 14 de janeiro de 2007. 
não ter uma pena cruel, desumana ou degradante e o direito à segurança pública das demais pessoas. Diante dessa colisão, imprescindível é a aplicação do princípio da proporcionalidade, que consiste em escolher qual o bem jurídico e seu respectivo valor terão maior importância em um dado caso concreto. Para o juiz do Tribunal Regional Federal da 2aㅡ Região, José Eduardo Carreira Alvim $(2007)^{19}$, ao defender a possibilidade de se utilizar a ação civil pública como forma de tutelar o direito à segurança pública, conclui que este direito é o "guardião dos direitos fundamentais, pois sem segurança todos os demais direitos valerão muito pouco ou quase nada, e o chamado Estado de direito se transforma no estado da desordem, da insegurança e do desrespeito à ordem juridicamente constituída".

Dessa forma, levando em consideração que entre os direitos fundamentais há uma hierarquia axiológica e havendo uma colisão entre eles, necessário se faz afastar um deles da incidência do caso concreto, sem que isto implique a não preservação de ambos.

\section{Conclusão}

Após todo um estudo, junção de conceito e opiniões, restou comprovado que a doutrina majoritária refuta a utilização do regime disciplinar diferenciado, por entender que o mesmo não é uma boa prática de segurança pública. Ademais, ficou demonstrado que a imposição desse tipo de sanção disciplinar potencializa os efeitos da prisionização, funcionando como autêntico aparato de violação à integridade física e psíquica do preso. Ressalta-se que a vigência do RDD, conforme salientado pelo Conselho Nacional de Política Criminal e Penitenciária, esbarra nos "direitos e garantias individuais consagrados pela Constituição Federal e por tratados que compõem o Direito Internacional dos Direitos Humanos". Entendem que com a adoção de Estado Democrático, Social e de Direito o preso deixou de se mero objeto, despojado de todos os direitos.

Destacou-se também a incompatibilidade entre o regime disciplinar diferenciado e a função ressocializadora da pena. O advogado e ex-ministro do Supremo Tribunal Federal, Evandro Lins e Silva já afirmava que a prisão não regenera, nem ressocializa ninguém; ela perverte, corrompe, deforma, avilta, embrutece, é uma fábrica de reincidentes, é uma universidade às avessas, onde se diploma o profissional do crime. Se a prisão ocasiona esses

19 Artigo obtido no site http://www.mundojuridico.adv.br/cgi-bin/upload/texto352.rtf. Acesso em 14 de janeiro de 2007. 
efeitos na pessoa, quiçá um regime de isolamento celular absoluto, onde se restringe de forma brutal os vínculos do detento com o exterior.

Ressaltou-se, ainda, que a partir da adoção do RDD, as prisões passaram a ser alvo de maio índice de violência, especialmente a violência coletiva manifestada nas rebeliões, reforçando o processo de vitimização do preso.

Após esse tópico, foi retratado que o RDD desrespeita o Princípio da Legalidade, já que as hipóteses de sua incidência contêm termos vagos que não permitem delinear qual a conduta típica a ser praticada pelo preso.

Outro ponto debatido foi a correlação entre o direito penal do inimigo e a política do regime disciplinar diferenciado. Nesse momento, evidenciou-se a incapacidade do Estado de manter e organizar os serviços de segurança dentro dos presídios, enxergando no recrudescimento das leis penais a salvação para todos os males. No entanto, tal prática além de ser ineficaz reforça o caráter simbólico do direito penal.

Por fim, foram apresentadas as opiniões favoráveis à aplicação do RDD nos presídios brasileiros, com ênfase à adoção do princípio da proporcionalidade que consiste em afastar a incidência de um direito fundamental quando houver colisão com outro direito de igual valor axiológico.

\section{Referências}

ALVIM, José Eduardo Carreira. Ação civil pública e direito difuso à segurança pública. Disponível em: <http://www.mundojuridico.adv.br/cgi-bin/upload/texto352.rtf>. Acesso em: 14 jan. 2007.

BARROS, Carmen Silvia de Moraes. O RDD (Regime Disciplinar Diferenciado) É UM ACINTE. Disponível em: <http://www.processocriminalpslf.com.br/rdd.htm>. Acesso em: 29 set. 2006.

As modificações introduzidas nos arts. 60 e 112 da LEP pela Lei 10792/03 e a jurisdicionalização e a individualização da pena na execução penal. Revista Brasileira de Ciências Criminais, v. 12, n. 48, p. 179-193, maio/jun. 2004.

CARVALHO, Salo de; WUNDERLICH, Alexandre. O suplício de Tântalo: a lei n. 10792/03 e a consolidação da política criminal do terror. Boletim IBCCRIM, São Paulo, v. 11, n. 134, p. 6, jan. 2004. 
DELMANTO, Roberto. Da máfia ao RDD. Boletim IBCCRIM, São Paulo, v. 14, n. 163, p. 5, jun. 2006.

FREIRE, Christiane Russomano. A violência do sistema penitenciário brasileiro contemporâneo: o caso RDD (Regime Disciplinar Diferenciado). São Paulo: IBCCRIM, 2005.

GOMES, Luiz Flávio; CUNHA, Rogério Sanches; CERQUEIRA, Thales Tácito Pontes Luz de Pádua. O Regime Disciplinar Diferenciado é Constitucional? O Legislador, o Judiciário e a Caixa de Pandora. Disponível em:

<http://www.bu.ufsc.br/ConstitRegimeDisciplinarDifer.pdf>. Acesso em: 10 jan. 2007.

GRECO, Luís. Sobre o chamado direito penal do inimigo. Revista Brasileira de Ciências Criminais, São Paulo, v. 13, n. 56, p. 80-112, set./out. 2005.

JAKOBS, Günther. Direito Penal do Inimigo: noções e críticas. Organização e Tradução: André Luís Callegari e Nereu José Giacomolli. Porto Alegre: Livraria do Advogado, 2005.

KUEHNE, Maurício. Alterações à Execução Penal. Disponível em: <http://www.bu.ufsc.br/ConstitRegimeDisciplinarDifer.pdf>. Acesso em: 10 jan. 2007.

MALAN, Diogo Rudge. Processo Penal do inimigo. Revista Brasileira de Ciências Criminais, v. 14, n. 59, p. 223-259, mar./abr. 2006.

MARCONDES, Pedro. Políticas públicas orientadas à melhoria do sistema penitenciário brasileiro sob o enfoque da função da pena vinculada à função do Estado. Revista Brasileira de Ciências Criminais, São Paulo, v. 11, n. 43, p. 248-260, abr./jun. 2003.

MENEZES, Bruno Seligman de. Regime disciplinar diferenciado: o direito penal do inimigo brasileiro. Boletim IBCCRIM, São Paulo, v.14, n. 168, p. 19, nov. 2006.

MIRABETE, Julio Fabbrini. Execução Penal: comentários à Lei 7.210, de 11 de julho de 1984. 11. ed. São Paulo:Atlas, 2004.

MORAES, Alexandre. Direitos Humanos Fundamentais. 6. ed. São Paulo: Editora Atlas, 2005.

MOREIRA, Rômulo de Andrade. O monstro RDD - É melhor chamar de Regime Disciplinar da Desesperança. Revista Consultor Jurídico. Disponível em: <http://conjur.estadao.com.br/>. Acesso em: 16 ago. 2006.

NUCCl, Guilherme de Souza. Manual de Processo Penal e Execução Penal. São Paulo: Ed. Revista dos Tribunais, 2006. 
PRITTWITZ, Cornelius. O Direito Penal entre Direito Penal do Risco e Direito Penal do Inimigo: tendências atuais em direito penal e política criminal. Revista Brasileira de Ciências Criminais, São Paulo, v. 12, n. 47, p.31-45, mar./abr. 2004.

REGHELIN, Elisangela Melo. Regime disciplinar diferenciad: do canto da sereia ao pesadelo. Boletim IBCCRIM, São Paulo, v.14, n. 168, p. 18, nov. 2006.

SILVA, Zilan Costa e. Breves considerações sobre o Direito penal do inimigo. Disponível em: <http://www.ibccrim.org.br>. Acesso em: 14 jan. 2007.

WEIS, Carlos. O Conselho Nacional de Política Criminal e Penitenciária entende inconstitucional o regime disciplinar diferenciado. Boletim IBCCRIM, São Paulo, v. 13, n. 155, p. 14-15, out. 2005. 